Journal of Qualitative Criminal Justice \& Criminology • 2021 | Volume 10, Issue 1

\title{
Forced Interactions with Sheriff Deputies Over Time and Their Influence on Stigma and Self Identities among Individuals Convicted of Sex Crimes
}

Lisa L. Sample ${ }^{1}$, Brooke Cooley², Tusty ten Bensel ${ }^{3}$, Carin $\mathrm{Hyter}^{4}$, Brett Hurley 5

${ }^{1}$ University of Nebraska at Omaha, ${ }^{2}$ Ball State University, ${ }^{3}$ University of Arkansas at Little Rock, ${ }^{4}$ Drug Court of Winona County, MN, ${ }^{5}$ Houston Police Department, MN 


\section{ABSTRACT}

This paper examined the perceptions of convicted sex offenders and their interactions with law enforcement over time. Specifically, we focused on how formal interactions influenced stigma management and self-identity transformation. For decades, scholars have proposed that identities and behaviors often result from interactions with others. Sex offender registration and notification laws force interactions between registrants and police agents for years, if not a lifetime. Given that desistance from sex offending is dependent on prosocial identity transformation, we analyzed interviews with 63 registrants to uncover how interactions with police promote or inhibit identity transformation over time. Our findings suggested interactions with police can influence the internalization of a "sex offender" label, can reaffirm non-offender role identities, but mostly have little to no effect on personal identity transformation over time.

\section{Introduction}

The term "convict" is a stigmatizing label that seeks to discredit one's identity in society (Meisenbach, 2010). Unlike stigmas based on physical or mental disabilities, a "convict" label can largely be managed through information management (Goffman, 1963), unless those "convicts" are people convicted of sex crimes. The boundaries of a "sex offender" label include cultural assumptions such as mental health disorders that require civil commitment after serving a criminal sentence. They are assumed to be at risk for reoffending regardless of treatment, similar to alcoholics consistently struggle with drinking behaviors. Many assume that their victims are predominantly children and they are capable of murder (Sample \& Bray, 2003). A "sex offender" label carries considerable negative and stigmatizing connotations that cannot be easily overcome.

Due to these assumptions, individuals convicted of sex crimes are mandated by law to provide their addresses, photographs, and other information to state and national sex offender registry websites (U.S. Department of Justice, 2020). Thus, government agents have become the information managers for people with criminal sexual deviancy, "sex offenders." The advent of the Internet, Freedom of Information Act, and judicial actors are often involved in stigma management by determining what is private and public information (Lageson \& Maruna, 2018). The ease with which "private" information has become "public" makes it essential for those labeled as "sex offenders" to learn how to cope with, mitigate, and interact with others, while living under this stigmatizing label (Mingus \& Burchfield, 2012). Scholars, however, seldom examine the degree to which labeled individuals actually internalize their stigmas, nor have we determined the effects that mandated interactions based solely on a "sex offender" status have on identity. Given that identity transformation from offender to non-offender is an essential element of desistance from sex offending and crime (Giordano, Cernkovich, \& Rudolph, 
2002; Maruna, 2001), it is imperative to understand how registrant/law enforcement interactions influence identity transformation over time.

Labels and identities are important as they are likely to be associated with behavioral outcomes (Burke \& Reitzes, 1981; Paternoster \& Bushway, 2009; Rocque, Posick, \& Paternoster, 2016), such as desistance. Since identities are not static and evolve within social interactions over time, we conducted life history interviews with 63 registered citizens in Nebraska. Specifically, we focused on how people convicted of sex crimes viewed themselves prior to conviction to establish base-line role identities and after interacting with law enforcement in the community post-supervision. Our sample consists of people who no longer have any criminal justice contact other than with sheriff deputies to fulfill their registration requirements. Through these life history interviews, we can see the process by which identities of people convicted of sex crimes are influenced by law enforcement interactions over time.

\section{Background}

Individuals convicted of sex crimes are legally and socially stigmatized (Mingus \& Burchfield, 2012; Tewksbury, 2012). A stigma is conceptualized as a mark of social disgrace or an attribute that disqualifies individuals from full social acceptance (Goffman, 1963). Various legal statutes may externally stigmatize people convicted of sex crimes, but that does not mean that these people internalize this label in a way that affects how they see themselves and behave (Evans \& Cubellis, 2015). There are three distinct approaches to determine perceptions of stigma or how people might internalization a label (LeBel, 2012). "Perceived stigma" is how individuals think about stigmatized groups in general, while the manner in which individuals believe public views of them personally is known as self-stigma or the internalization of a label. Moreover, experiences of discrimination because of a stigmatized group affiliation are considered "enacted stigma"; however, individuals can mitigate living a life as a stigmatized people by adopting and prioritizing role identities.

The consciousness of the self is a reflexive behavior that grows as people interact within multiple environments (Cooley, 1902; Goffman, 1963; James, 1890; Mead, 1934). Individual identity emerges through social interactions within complex societies that offer opportunities for multiple roles or identities. People convicted of sex crimes may adopt role identities of husbands, fathers, loyal friends, valued employees, and other socially accepted roles as they change their environments and interactions. For instance, sex offenders can be seen as "good fathers" during parent/teacher conferences, "good husbands" at home with their partners, and "loyal friends" while at the movies without recognition of their "sex offender" label. Although people convicted of sex crimes may be officially labeled as "sex offenders," they have opportunities to diminish the weight they give this label when constructing self-identity narratives based on their various roles in society (Maruna, 2001). 
Relevant to desistance from sex offending and crime, Stryker (1980) suggested when individuals adopt various roles in society, they internalize the social expectations that come with these roles, including language, symbols, signs, and gestures. People convicted of sex crimes can appear as conventional and law-abiding citizens as they lose their use of "sex offender" language and gestures, and adopt identities of being prosocial citizens (Sampson \& Laub, 2003). For instance, positive social interactions and acceptance from others as a husband can help internalize and solidify a husband identity (Powers, 1973). In contrast, negative social feedback can challenge the husband identity verification and disrupt identity formation (Zanna \& Cooper, 1976). It can also inhibit criminal desistance by prohibiting identity transformation from "criminal" to "pro-social citizen."

\section{Identity disruption and verification}

For this study, we focused how interactions with law enforcement agents may disrupt the transformation of pro-social role identities. There are four ways in which identities can be interrupted (Burke \& Stets, 2009, also known as identity crisis by Erikson, 1959). A type I interruption includes the "broken loop." When activating a new identity (i.e. ex-offender, reformed citizen), a highly organized and continuously operating feedback loop occurs that adjusts outputs to maintain balance between inputs and identity standards. Visits to and from law enforcement agents could result in the lack of verification of a new identity; thus, breaking this loop.

Type II interruptions include interference from other identities. Since individuals assume multiple roles in society, it is possible that one role identity may come into conflict with another. For instance, the husband identity can be challenged by law enforcement officials as the sole basis of interactions with persons convicted of sex crimes is the "sex offender" label. Further, Type III interruptions occurs within over-controlled identities, or when the maintenance of one identity requires more attention and resources than other identities adopted, hence verifying one identity above all others. Interactions between persons convicted of sex crimes and law enforcement agents could easily draw more attention to the "sex offender" role at the expense of other prosocial identities.

Last, type IV interruptions are referred to as episodic identities. People assume multiple roles in society, but different role identities rarely interact simultaneously. The husband identity is rarely perceived while assuming the employee role. The interruptions of identity verifications, which are the producers of self-esteem, demonstrate the evolving nature of identities and how interactions within different environments influence them. For this study, we assumed the way in which law enforcement agents interacted with sex offenders during registration processes could verify or disrupt the creation of the "new self" or the identity verification needed for desistance. 


\section{Stigma internalization and management}

As Matsueda (1992) noted, labeling theory research often ignores intervening components between ascribing labels to individuals and their acceptance or internalization of them. Despite degradation ceremonies and negative social interactions based on a stigmatizing label, some individuals, for example "convicts," can still resist adopting a "convict" identity (Hochstetler, Copes, \& Williams, 2010; Maruna, 2001). Goffman (1963) suggested this is possible when people accept, avoid, reduce, and/or deny stigmas. It may be difficult to avoid or deny "sex offender" stigma while being forced to interact with sheriff deputies on this basis at least four times a year.

Although often difficult to deny or avoid stigmas, there are stigma management strategies including reframing/recalibrating personal ideologies, creating social buffers, confronting people about their taint, and/or engaging in defensive tactics (Ashforth \& Kreiner, 1999). Reframing/recalibrating ideologies emphasize positive attributes, whereas social buffers are created among other "in-group" members dealing with the stigma. People can confront others and rebut discrediting information by extolling value contrary to stereotypes and defensive tactics that include gallows humor, tolerating the status quo, comparing self to worse-off others, condemning those doing the stigmatizing, blaming the stigmatizers, and distance the self from stigmatizers. Also, Hochstetler, Copes, \& Williams (2010) suggest that those with negative labels, such as violent criminals, can create "authentically" violent others against which they compare themselves. For instance, the purpose of violence, violent intensity, and the victims of violence are characteristics by which violent offenders compare themselves to similarly situated others. "Authentically" violent people seek out violence, use it indiscriminately, and use it excessively. If people's criminal events did not possess these qualities, then people do not have an "authentic" violent identity and their actions are placed into situational contexts.

Similarly, Maruna (2001) suggested that redemption scripts often help people manage stigma. Redemption scripts begin by establishing the "goodness" of narrators and the external circumstances under which they became criminals - circumstances over which they had no control. Some outside force, such as a person who believed in the narrator's goodness, empowers them, which propels narrators to give something back to society for the trouble they have caused. Rather than "knifing off" sex offenders' pasts, the redemption script allows people to re-write their shameful pasts into a prelude to a purpose-driven life. These redemption scripts are consistent with what we know about self-identity. The self-schema is relatively stable over time because people select from their experiences those that support the "true self," or peoples' understanding of their nature or their core of normalcy (Lofland, 1969). By referring back to conventional role identities prior to conviction, sex offenders can emphasize the normalcy of their life history, suggesting they were just like everyone else all along (Maruna, 2001). 
For years, scholars have suggested that registration and notification laws have little deterrent effect on sexual reoffending (Evans, Lytle, \& Sample, 2014; Sandler, Freeman, \& Socia, 2008; Vess, Day, Powell, \& Graffam, 2013) because factors such as social stigma and unemployment may make reoffending among registrants more likely (Frenzel, Bowen, Spraitz, Bowers, \& Phaneuf, 2014; Levenson \& Cotter, 2005; Tewksbury, 2005; Zevitz \& Farkas, 2004). Despite these findings, however, few scholars have directly investigated people convicted of sex crimes perceived selves and stigmas and how interactions with police agents over time may influence identity processes. This study provides insight into this gap in the literature by examining how registration-based interactions may influence the internalization of "sex offender" stigma and prosocial identity construction.

\section{Sex offenders and their interactions with law enforcement officials}

We could find no studies on registrants' perceptions of their interactions with police, but there is existing research that highlights law enforcement officers' opinions of sex offender laws (Harris, Levenson, Lobanov-Rostocsky, \& Walfield, 2018; Walfield, Levenson, Cubellis, Harris, \& LobanovRostovsky, 2017). For example, Powell and colleagues (2014) examined police interviews with sex offenders as part of the registration process. They found that establishing relationships between officers and offenders enabled proactive support for offenders and encouraged a lack of recidivism. They emphasized the importance of engagement and relationships based on trust to improve the efficacy of registration laws. Bailey and Sample (2017) examined the relationship between probation/parole officers and sex offenders in the community in terms of social distance, or familiarity and trust, established through interactions. They found "perceived" stigma in that sex offenders as a group were believed to be irredeemable, which influenced the way in which interactions began between officers and registrants. Over time, however, the social distance between officers and offenders decreased, trusting relationships were formed, and officers became part of registrants' social support networks. These relationships helped "new" identity verification to be achieved.

Directly relevant to this study, Lea, Auburn, and Kibblewhite (1999) examined perceptions and experiences of professionals, including police officers, who worked with convicted sex offenders. These scholars found that professionals' attitudes toward sex offenders had both positive and negative elements. They found professionals experienced tension between the need to develop relationships with sex offenders in their duties, while simultaneously balancing their desire to ensure they had no relationship with offenders who they found personally abhorrent. This tension reflected the professional-personal dialectic that is informed by broader social contexts, cultural attitudes, and myths found within the public domain. Professionals feared the secondary stigma that can be associated with befriending sexual criminals. To counter the professional-personal dialectic, they trained themselves to separate the person from the behavior, which enabled professional-personal 
working relationships with sex offenders. This allowed them to covertly assess risk levels, monitor social circumstances, and discuss situational reactions.

"Perceived" stigma, or the attitudes and opinions of police toward people convicted of sex crimes formed within the context of social and cultural criticism for sex offending, can influence how law enforcement professionals approach their initial interaction with sex offense registrants. This predetermined bias likely affects interactions, at least until professionals come to know sex offenders as people and not crime types. Law enforcement/sex offender interactions may take the same two approaches found in correctional counseling (Lofland, 1969). Police agents may partake in deviantsmithing where interactions purposely stigmatize registrants and make them feel as if they have some disease or pathology. In contrast, interactions may take the form of normal-smithing, in which police agents minimize the "sex offender" stigma and offer words and gestures that reflect a belief that registrants are normal human beings. Either way, these interactions may influence how people manage their discrediting label. Although we have some idea of the perceptions police have about their interactions with sex offenders (Lea et al., 1999), absent from the literature is how sex offenders perceive their interactions with police. It seems particularly relevant to the study of desistance and public safety to understand how interactions with police make registrants think about themselves. For some registrants, the interactions they have with police will be the longest relationship they have in life, which makes these interactions important to the notions of personal identity and traditional notions of informal social control.

\section{Research design}

We conducted semi-structured, life history interviews with a snowball sample of registrants in the community $(n=63)$ to determine how they saw themselves before conviction, to establish role identity measures, and after interacting with deputies. In Nebraska, all registration and notification processes are conducted by state patrol, which relegates these duties to county sheriff departments. To better isolate the effects of sheriff/registrant interactions on identity, none of the 63 subjects were on probation or parole at the time of interviews. Over the course of our interviewing, the only legally mandated interactions these 63 subjects had pertaining to their "sex offender" label were their registration and compliance experiences with sheriff deputies. Specifically, life history interviews focused on registrants' self-identities before conviction and their identities and interactions with sheriff deputies post-correctional supervision. For the current sample, police interactions occurred every three months when registering and during home compliance checks.

The current sample was in the community post-conviction for an average of 9.4 years. Their only interactions based solely on their "sex offender" label was with sheriff deputies during these years. Interactions between people convicted of sex crimes and sheriff deputies varied in length depending on the jurisdiction. For instance, home verification visits by sheriff deputies could last five minutes to 
one hour, depending on the county in which they occurred and the deputy conducting the visit. These 63 registrants interacted with sheriff deputies between a total of three to four hours per year. We could find nothing in the literature to suggest that the length of interactions, whether they be minutes or hours, influenced identity. Rather, the perceived quality of interactions in terms of reaffirming or refuting new identities is what affects identity transformation (Burke \& Stets, 2009). Last, registrant interviews were triangulated using interviews (either face-to-face or via email) with 26 family members who included romantic partners, siblings, and parents. Also, we have observational data of deputy/registrant interactions for two subjects over a two-year time span that includes over 40 pages of notes on how interactions vary across officer and how interactions evolve over time.

\section{Data collection}

We recruited participants through a snowball sampling technique, which is often used in qualitative research and hard to reach populations (Anderson, 2000; Jacobs \& Wright, 2008; Wright \& Decker, 2011). Registrants are often reluctant to share their experiences with others in fear of stigmatization, harassment, and even judgment (ten Bensel \& Sample 2016, 2017); therefore, we worked with a private advocacy group for registrants to recruit subjects and their family members to participate in this study. For this study, we restricted our sample to only those who no longer had any contact with probation/parole and those forced to register four times a year. Sample restrictions helped us better isolate the influence of registrant/deputy interactions on registrants' identities beyond any other criminal justice influence. We began interviewing subjects in 2012 and we continue to have contact with these 63 subjects through 2020. We interact with these subjects on average of 2.4 times per year. Most interactions since initial interviews and follow-ups have been subject-initiated, but we do email participants if we have not heard from them in 6 months.

Family members were recruited for our study by registrants. For this study, 26 family members were associated with the 63 subjects. Collectively, interviews with registrants and their family members have generated over 4800 pages of transcribed data that included both initial and follow-up interviews. In addition, we have acquired over 300 pages of emails from study participants that were subject-initiated. Some subjects or family members blogged about their experiences over time, and we were given the URL sites for their private blogs, which accounted for approximately 400 pages of text. Registrants in this study were all in the community with ample opportunities to reoffend, and no one self-reported sexual reoffending. The lack of reoffending was triangulated with arrest data and information from registrants' family members.

Last, two subjects in this study allowed a researcher to accompany them when registering their names, addresses, and other information with law enforcement professionals. These observations helped us triangulate data gained from these subjects. Over 40 pages of hand-written notes were created across two subjects for a period of two years of registration visits to police. Observational notes highlighted 
non-verbal cues and communication by both registrants and sheriff deputies, such as eye-rolling, hand-waving, smiling, and other examples.

Our primary data were in-depth, semi-structured interviews conducted face-to-face, on the phone, or via email. We used informal conversational interviewing techniques, in which the researcher was a "traveler" (Kvale \& Brinkman, 2009) in the lived experiences of our participants pre- and post-sex crime conviction. They immersed us into their lives and noted how they changed over time. These conversational interviews began by asking, "would you like to tell me about your experiences with sex offender registration?" The lack of structure in these interviews allowed them to discuss anything they wished, which permitted us to determine what registrants found most pressing to share. We asked follow-up questions about law enforcement interactions, such as "how would you describe your interactions with deputies who conduct compliance checks?" Initial interviews were all face-to-face, lasted on average of 2.3 hours, and follow up interviews were conducted through face-to-face meetings, phone calls, email correspondence, and/or blogs. The average number of contacts with participants was 2.4 times per year beginning in 2012 and continuing through 2020.

\section{Sample characteristics}

Our sample was all White, male, had "some college" education, and ranged from 27 to 82 years old, with an average age of 42.2 . Pre-conviction salaries ranged from $\$ 45,000$ to $\$ 140,000$ annually, whereas post-conviction salaries ranged from $\$ 15,000$ to $\$ 70,000$. The sample of family members used for triangulation purposes were $99 \%$ female, 100\% White, ranged in age from 22 to 64 years old, and the overwhelming majority of women were spouses/cohabitants of registrants. Also, two mothers of registrants were interviewed. We asked subjects to estimate, in minutes, the time each offender spent with sheriff deputies while registering in person and multiplied that by the 4 times a year. We also had subjects estimate the average length of deputies' home compliance visits and multiplied that by the number of home visits subjects experienced a year. We totaled the time and calculated an average time subjects spent interacting with sheriff deputies while registering and during home compliance visits, ranging from 1.9 hours a year to 5.3 hours a year depending on county and officers involved in registration processes.

\section{Analytic techniques}

Narrative research collects data as life stories provided by narrators, which include individual, situational, historical, and cultural contexts (Lieblich, Tuval-Mashiach, \& Zilber, 1998; Pierce, Maynes, \& Laslett, 2008). The story itself is interpreted as one's identity- a story created, told, revised, and retold throughout life (Lieblich et al., 1998). The basis of narrative analysis lies in two dimensions, holistic v. categorical and content v. form approaches. We began our narrative analyses by open coding (Corbin \& Strauss, 2015) or taking a holistic-content approach, meaning the life stories of narrators 
were repeatedly read as wholes and attention was paid to explicit content or parts of the interviews pertaining to identity pre-conviction and during interactions with deputies ("stories within stories") (Lieblich et al., 1998). This is considered a global impression of stories.

Once we uncovered the "stories within stories," we moved to a categorical-form approach to data analysis (Lieblich et al., 1998). This approach focuses on discrete stylistic characteristics of defined units of narratives and allows us to learn about the narrator that may not be apparent from a general read of content. For instance, cognitive skills or irrational thinking, inadequate differentiation, lack of responsibly, and inability to maintain simultaneous perceptions can be uncovered in how narrators choose to tell their stories. Emotions and coping strategies are also discernable when examining linguistic choices in stories. Both cognition and emotion are relevant to identity creation and transformation.

The parts of subjects' stories pertaining to life before conviction and deputy/registrant interactions were read line by line and analyzed for structure. The structure of the stories refers to the "plot" of the story, the sequencing of events, its relation to time, its complexity and coherence, the style of narratives, and subjects' emotions generated by stories told. We chose to analyze the form of stories (passive v. active voice, metaphors used, etc.) because "it uncovers the deeper layers to the narrators' identities (Lieblich et al., 1998, p. 13)." Also, adverbials such as "suddenly," mental verbs like "I thought," tense of verbs used, and intensifiers such as "really," were all noted as axial codes within these data (Corbin \& Strauss, 2015) to help categorize narratives structures. From axial coding, comparisons across and within narratives were made and themes were uncovered within the data pertaining to how interactions with deputies influenced subjects' identities.

Because we conducted life history interviews, we could discern a sequencing of events. This gave us the opportunity to observe change within the narratives. We chose to present our findings in narrative fashion, which is consistent with story-telling and narrative analysis (Pierce et al., 2008), so readers could see how the evolution of interactions influenced identity. We do not present stories from all 63 participants, but rather we have chosen to tell stories generally representative of the themes uncovered.

\section{Limitations}

As with all research, the current study has limitations. The current participants were all male and white. This demonstrated sample bias innate in a snowball sampling strategy (Wright, Decker, Redfern, \& Smith, 1992); however, our sample is a common demographic trend in sex offender research. Additionally, a lack of random sampling limited the external validity of the study, inhibiting us from generalizing our findings to a larger registrant population; however, generalizability was not our intention and a higher emphasis was placed on internal validity rather than external validity. As 
discussed previously, the sex offender population is a difficult group of individuals to interview because they are a hidden population (Klein, Bailey, \& Sample, 2018). Sex offenders are often reluctant to discuss their crimes, perceptions, and experiences in fear of judgment, stigmatization, and harassment (ten Bensel \& Sample 2016, 2017). The goal of this study was to understand identity construction and stigma management among this group; therefore, a more representative sample would be difficult to obtain.

While the goal of the current study was to isolate the effects of sheriff/sex offender interactions on stigma management and identity construction and interruption, we recognized that other interactions with individuals (i.e. probation, parole, inmates, and non-criminal justice agents) also had an impact on stigma management as registrants reintegrated into communities. The examination of these interactions were beyond the scope of this paper; however, previous studies have focused on interactions with probation and parole officers (Bailey \& Sample, 2017), interactions with others bearing the same "sex offender" stigma (Sample, Cooley, \& ten Bensel, 2018; ten Bensel \& Sample 2016, 2017), the effects of incarceration as a deterrent to sexual reoffending (Cooley, Moore, \& Sample, 2017), and the ways in which "sex offenders" families cope with secondary stigma (Bailey \& Sample 2017). Although we do not examine all interactions relevant to stigma management and identity construction in the current study, to our knowledge, this is the only study that has focused on registered citizens' perceptions of their interactions with police and how it impacts their stigma management and selfidentity. Nonetheless, these caveats should be acknowledged when reading our results.

\section{Results}

Life history data are by nature subjective and personal (Pierce et al., 2008), but narrative analysis of these data allows us to understand individual agency and motivations as they operate and change through time. Narrative analyses often begin by contextualizing the history behind narrators' story telling. We then begin our analyses by contextualizing how registrants saw themselves before they were convicted for a sex crime to provide a base-line against changes over time could be compared.

\section{Identity pre-conviction}

The overwhelming majority of participants $(n=61)$ in this study did not see themselves or interact with others as "sex offenders" before their convictions. For example, Pablo stated, "I was an idiot. A regular guy who went online to meet women and ended up with one who said she was 19 and she was really 15." Pablo conveyed that his crime was unintentional and had he known that she was underage, he would not have engaged in intercourse with her; therefore, he did not consider himself a "sex offender." Similarly, Jeremy related,

I was being shipped over to Iraq so I downloaded a bunch of porn to take over with me and five images had girls under 18 , so I got busted for child porn and court marshalled. I was not looking 
for kiddie stuff, it just was included in these big batches of porn. I had not even opened it, but I did download it on my work computer, so it was easy for the military to catch it.

When offering their narratives, most of the participants described themselves as "average guys" or "regular dudes." They often contextualized their sex crimes as some episode in an otherwise average life (Maruna, 2001). As Hochstetler and colleagues (2010) suggest, they did not see themselves as "authentic" sex offenders because the circumstances of their crimes were not excessively violent, they often had consent, and they were not seeking out ways to violate sex offense laws. Prior to conviction, they had role identities as boyfriends, sons, parents, husbands, employees, or bosses, but never saw themselves as "criminals" or "sex offenders." The "average guy" persona was consistent with the notions of redemption scripts. To cope with the stigma of the "sex offender" label, most subjects retrospectively assessed their identities as "normal" (Maruna, 2001), and loved ones triangulated these findings of normalcy. As Martha stated, "my husband was just like other guys I had dated in high school. He was good-looking, smart, and very funny. There was nothing to indicate he would look at child porn." Still, it is possible the assertion of normalcy allowed subjects and loved ones to recast their past, present, and future selves by aligning themselves with conventionality (Opsal, 2011), thus mitigating their official stigmatizing label.

Only two participants in our study identified as having a stigmatizing sex offender identity prior to their convictions. For example, Jack developed a "sex offender" identity by the age of 13 after being ejected from his first foster home for inappropriately touching another young male resident. From this point on, he explained "they moved me to another foster home and I did the same thing. Then, they moved me into a group home for boys, all with sex crime issues." Jack explained:

After the group home, I knew I was different, but worked really hard to redirect my thoughts and did pretty good until I moved in with my uncle and met these two boys in his trailer park. They were outside a lot and always alone. I struck up a relationship with them, and then one with their mom so I could be closer to the boys. Eventually our relationship became sexual.

Scott also had a "sex offender" identity before being convicted of sex crimes. He stated, I loved being around kids. They are so simple and don't come with the bullshit adults do. They are pure. I would fall in love with them then become sexually attracted to them, and eventually I would molest them, but I never had intercourse with them. Of course, I knew it was wrong, but I really didn't have anyone else in my teens and 20s besides the kids I knew. We loved each other.

Even those who perceived themselves with sexual deviancy problems and had developed a "sex offender" identity were careful to provide details that deemphasized violence. Still, the overwhelming 
majority of this sample identified themselves as "normal" men who were computer analysts, priests, teachers, doctors, and had other employment-related normal identities.

\section{Disruption of conventional role identities}

Criminal justice processing (arrest, conviction, sentence) began to disrupt conventional role identities for registrants. Type II and III identity interruptions followed the sentencing phase, particularly for those sentenced to prison. An official "convict" label interrupted traditional role identities as fathers, husbands, valued workers and forced individuals to spend more resources on managing their "sex offender" label than reinforcing conventional role identities. Prison sentences played a large part in internalizing a "criminal" identity but not necessarily a "sex offender" identity. Those who were incarcerated transformed their identities to "criminals" by interacting with other inmates, guards, and counselors. Irving explained, "I was in prison, I couldn't avoid being a "criminal" to all the other criminals in there. We had all done something wrong." Subjects who were punished by community supervision interacted with probation and parole officers who consistently reminded them of the "special conditions" under which they were to live, but in prison they all live as "criminals." Irving noted, "in prison, it's hard to see your parents, wife, kids, friends because who wants to sit in a prison waiting room."

Spatial closeness and consistent interactions based solely on a "criminal" status helped transform the identity of once perceived "conventional" selves into "criminal" selves, but these "criminal" selves did not sufficiently transform them into "sex offenders" and all that applies. Interactions with prosocial loved ones and others was disrupted making a "criminal" identity at the very least a "situational" one (Stone, 1962) or one produced through the announcement or presentation of the self in specific interactions (Scott, 2015). Despite probation and parole officers, as well as prisons developing specialized units for sex offender management, all but two of the participants did not internalize a

"sex offender" identity regardless of criminal justice processing and treatment. In some ways it was as if people developed an authentic "criminal" identity based on their criminal convictions but not an authentic "sex offender" one. The policy implications of this finding are interesting in that all the resources spent to declare these men as morally challenged "sex offenders" rarely created a "sex offender" identity.

\section{Identity over the course of interacting with sheriff deputies}

Registration processes and compliance verification visits begin the minute registrants are released into the community. Most in this sample had been registering for years when our first interviews began in 2012. Many, however, were assessed as low risk and not subject to the public registry until 2009. There was much anger that lingered among our research subjects in 2012 when we began this study because of the perceived nature and unfairness of "ex post facto" legislation. 
Also, this study's focus is on how periodic interactions with sheriff deputies influence identity transformation, so included in these analyses are subjects whose only interactions with criminal justice agents under a "sex offender" label was during registration and compliance experiences. Obviously, in many cases participants had interreacted with probation or parole officers under a "sex offender" label, while interacting with police. In Nebraska, however, no sex offenders are supervised for longer than five years, so this gave us the opportunity to isolate interactions with sheriff deputies as the only ones registrants were having based solely on their "sex offender" status. In all other informal interactions, registrants were in control of providing information about their convictions if they chose. They could share or not share information about their offender stigmatization.

We found three consistent themes or identity-related outcomes resulting from registrants' interactions with deputies over time. Interactions could verify conventional role identities in ways that mitigated the "sex offender" label, interactions could remind people of their label, and/or interactions with sheriff deputies had little to no effect on any role identities developed pre- or post-conviction. To be clear, these themes or outcomes were not mutually exclusive. Because we have data over time, we found that circumstances of interactions could affect identities in episodic fashions. For instance, the influence of interactions changed as the participants of the interactions changed. Nonetheless, our themes are based on a totality of interactions over time. We have chosen to present our data in a "storytelling" fashion (Pierce et al., 2008) so readers can notice how the nature of interactions between registrants and deputies changed over time.

\section{Verification of conventional role identities}

Jack's story demonstrates the evolving nature of registrant/deputy interactions. Jack was age 33 when first interacting only with deputies based on his label. He was unmarried, had found a laborer job, and had no children. He was convicted of two counts of rape and served 9 and $1 / 2$ years in prison. He was placed on parole supervision for six months and finally "jammed" or served $100 \%$ of his sentence and was released from supervision in year 10. He recalls his experiences with registration and compliance visits and interactions with deputies.

When I went to register the first time, I was so nervous someone in the station would pick a fight with me. We are made to wait to register in a room with other people visiting the station to report crimes and stuff. I felt like everyone in the world knew I was a sex offender, like there was a letter on my forehead. Everything was very official, name, address, any changes and done. Then I see this same guy pretty much every 3 months since. After registering for a year, and no violations, me and the guy started to talk. He would ask me about my job, congratulated me on my promotion, congratulated me when I bought my house. The same thing happened with cops who stopped by my house. After a year, they would knock on the door and say 'good, you're here" and they were ready to go. I asked them in for a pop or something but most time they refused. 
Once I got married and my wife has kids, they started coming in and looking around the house. Even talked to the kids a few times, but they were pleasant enough. Now they are back to only knocking and checking that I live here with my wife and kids.

When I first got out [of prison], I was so afraid everyone would be against me because of what I did, but the longer it goes, the more people seem to be in my corner. The guy at the registration desk was glad when I got married and now when I go in we talk about the trouble with teenagers. I even invited a retired cop to my wedding who used to work with me. Now police in [another town], they can be real nasty and make you feel bad, but so many other people are in my corner now it doesn't bother me much. The cops are just doing their job, and though I wish I didn't have to take time off work to register, I don't mind. They run me through pretty fast so I can hopefully get my paperwork done on my lunch hour. My boss is really cool about giving me the time it takes to register.

Researchers accompanied Jack to the sheriff office to update his registration information 12 times during the course of his interviews from 2012-2019. We observed his deputy interactions and determined how accurate his interpretations of his interactions may be. We observed a "professionalpersonal dialectic" or a clear delineation between "us" or deputies and "them" or registrants that was deemphasized over the observation time. A counter separated registrants and deputies until registrants were called to the registration desk. Over time, much of the formality of registration experiences waned as Jack and deputies created social distance. We observed laughing and smiling and casual conversation between Jack and deputies. Deputies began to slump when talking with Jack as if relaxed. Clearly Jack was not misinterpreting verbal or non-verbal cues of familiarity and rapport. Deputies were taking some interest in his life and well-being.

Once off supervision, Jack's interactions with deputies began to exhibit decreases in social distance as he and deputies became familiar with each other's professional and personal lives. Social distance refers to the level of rapport and familiarity between criminal justice agents and registrants (Bailey \& Sample, 2017). The more social distance between officer and offender, the more likely the relationship can influence identity and behavior. Jack finds the deputies involved in his registration experiences helpful to his non-sex offender identities. Deputies reinforce his identity as a "husband," when they ask him about his wife, his identity as "an employee with promotions" when he and officers commiserate over their workloads and overtime hours, and as "stepfather" when they swap stories about how difficult it is parenting teenagers. Since Jack is a lifetime registrant, it is almost as if deputies have become some social support for his evolving attempts at child rearing a teen. Deputies talk with him about their wives after asking about his, making Jack feel as if he is part of the in-group of husbands. Interactions with deputies continually help Jack feel as part of "us" rather than "them," which likely affected his confidence in applying for a promotion at work, asking a woman to marry 
him, and taking on step-parenting responsibilities. Overall, Jack and 18 others (30\%) mentioned improvements in prosocial role identities resulting from interactions with police.

Social distance and the "professional-personal dialectic" can vacillate between positively and negatively influencing identity over time as we examine within narrative comparisons. Ferdinand, age 82 when telling his story, was convicted of two counts of sexual abuse of a child. He served three years in prison and five years on supervision. His interactions with deputies were typical of others with similar convictions:

There is this big room where everyone was waiting to talk to the cops, and then out of nowhere an officer pops his head out of another room and yells 'sex offenders' which is our cue to go into the registration room. Right there, I was pissed about being called a sex offender in front of all those people and figured someone would likely wait until I left the police station so they could beat me up. Once I was in the littler room, there were others there and we all just kind of avoided looking at each other. I didn't really talk to the cops at all, but after a while you start getting to know the registration guy. He'd call me to the desk by name and asked how I was doing. I remember when I told him about my heart operation, he seemed to care. He felt bad I didn't have any family to care for me and had no problem with me living with another person on the registry. He seemed to be happy I had someone to take me to appointments. Then I had to move out.

When I went to change my paperwork, a different guy was at the counter, different than the usual guy. I felt like he interrogated me about where I was living, who else was there, were there any kids, and I told him I was living alone now in an apartment. Wasn't too long after that I got a visit at home by a state patrol guy. It was weird because I have only gotten one of those before while living with [roommate]. He marched around the apartment looking at my phone, looking for a computer, looking through my CD collection. Then he asked me about being retired and talked about how excited he was to retire. I told him it was great in some ways but really boring in others. When he left we seemed to be on friendly terms.

After that visit pretty much the same guy is there when I go to register. He asks me about my health. I told him I had no changes to make on my forms, and he thanked me and I was done. For the last few years, I bet I only spent about 10 minutes to register. It is still a pain though since there is only one station I can register and I have to take the bus. I don't get many home visits from state patrol anymore either. They know I am no danger to people.

Only select interactions with deputies reminded Ferdinand that he had a "sex offender" label, and those were interactions in which the deputy had changed and social distance decreased. As time passed, however, both he and the new registration deputy became comfortable with one another and trust was built between them. Ferdinand no longer assumed the deputies were "out to get him" and 
deputies no longer monitored his residence and rarely stopped-by. These findings suggest that even when one player in a didactic relationship changes, over time their associations can grow to a level of intimacy that made Ferdinand feel like a "man," a retiree, a member of society, rather than making him feel as a dangerous "sex offender."

\section{Reinforcement of "sex offender" labels}

Bert, 53 years old at the time of interviews, had been registering for ten years post-supervision, and was arrested and placed on probation for 'improper touching of a minor'. He was married in 2012 and unfortunately got divorced in 2016. He recalls his registration and compliance check visits. One must understand the context of Bert's crime in that he never saw what he did as a sex crime. He had not served time in prison so he was not that "bad of a guy." He may acquiesce to being a "convict" or "criminal," but rejects the "sex offender" label and resents being made to interact on the basis of this label every three months.

I am not or have never been a "sex offender." I am not like those other guys who have to register, but when I go to register, I am treated like everyone else. They [deputies] look at me like I am a scum-bag. No matter whether I go down in a business suit or flannel. I suppose I am a bit belligerent when I register, but that is because it is not fair. If LB 1199 [policy revision bill to adapt the state to the Adam Walsh Act] had not passed, I would be off the registry by now.

So, when I go down to register, I basically just throw my license on the counter and say no changes. The desk guy has me sign my papers and I am out, but it is still a pain registering. Why can't we just report no changes online and save some time. Why do they have to see me in person, to make sure I'm behaving? What are they looking at me for, to see if I look like a sex offender or am a danger to kids? I get even more upset when they [state patrol officers] come to my house. I keep an eye on them the whole time they are there. If they want to look at something, I ask if they have a warrant. Once my girlfriend was there and they started asking her questions about me, so I had to tell her she had the right not to answer.

I did my time. When are they going to leave me alone? I got help, I take my meds, I have been off probation for 10 years without incident. What more do they want from me? I am no danger, so why should I leave work to register, why give up my time with my grandkids to register? I am sure as hell not taking the kids to the station with me.

I work and live a quiet life like everyone else. I make a decent living, share time with my kids and grandkids. It just seems useless to make me come in every three months to report no changes in my address. It is even more useless to stop by my house and take time out of my day just to see if I live there. I just want it to end. 
In this case, and 16 others (25\%), registration and compliance experiences did appear to disrupt the verification of conventional prosocial identities by reminding people of their "sex offender" status. As Bert's story indicates, Type II, III, and IV identity interruptions occurred before, during, and after interactions with deputies and officers. He clearly finds that the legal reminder of his "sex offender" role conflicts with his "grandfather" role, that at times the maintenance of his "sex offender" label requires more mental energy than the maintenance of his employer, boyfriend, and grandfather roles, and during compliance checks his "sex offender" label and his identity as boyfriend were forced to interact. At that moment, he was forced to acknowledge his "sex offender" status which disrupted his identity as boyfriend, at least for one hour.

Researchers had the opportunity to observe ten of Bert's registration visits with sheriff deputies between 2012 and 2020. We observed eye rolls from officers upon Bert's approach to the registration counter, implying that Bert was well known by officers. There was no friendly banter initiated by officers or by Bert. Bert's heavy sighs indicated his contempt for the process. After registration was complete, he spoke to researchers about it for over an hour explaining his anger about the process and his emotional pain over not being allowed to move on from his criminal incident.

Bert seems to have created a "authentic sex offender" identity against which he compares himself. Hochstetler and colleagues (2010) examined how drug "hustlers" distinguish themselves from "crack heads." Although both "crack-heads" and "hustlers" are both involved in the drug trade, "hustlers" presented themselves to researchers as being clean, cool, owning things, and having hearts. In contrast, "crackheads" had none of these qualities. Bert has verbally constructed himself as different than other labeled "sex offenders." Bert's actions were not crimes because he gained consent from his 16-year-old victim, his actions were not violent, and no force was involved. He clearly had great disrespect for officially-labeled "sex offenders" whose actions involved force, harm, and violence and resented being placed in the same category.

\section{No influence on identity verification or transformation}

More common were the cases where interactions with sheriff deputies had no influence at all on how registrants saw themselves over time. Regardless of perceiving a "criminal" or "sex offender" identity, $45 \%$ of participants found their interactions with deputies had little to no effect on how they perceived their stigmas or themselves. The registration process and interactions surrounding it were perfunctory exercises similar to buying groceries or paying rent. For instance, after interacting with police every three months for 9 years, Clark (41 at time of interview) explained:

When I go in to register, I just fill out my paperwork and go. Sometimes I tell them things like about my promotion at work and they are happy for me. They seem to care how I am doing. They ask about how work is going and about my nieces ... Cops coming to my house tell me how great 
my house looks now that I painted it. They really seem to understand that I'm not the same person I was when I went to prison.

Clark, who was convicted on child pornography charges, has positive interaction with deputies, they do not seem to change who he believes himself to be. He entered interactions projecting his employee and home-owner status and exited those interactions with those statuses intact.

Another example lies in the experiences of $\mathrm{Hal}$ (37 years old at time of interview), who was convicted of sexual abuse with a minor. He explains:

Registering for me is like renewing my car plates-it may be a pain but you have to do it so just do it and move on. I really don't talk to anyone when I go into register because it is often busy over the lunch hour. Cops give me my paperwork and I sign and am back to work. It would be nice to be able to register online, but whatever.

Cops do stop by my house to check to make sure I live there. Since I work during the day, they usually just leave their card and I call them when I get home. I have been registered for so long, they really don't come over anymore once I call in. I know some guys feel bad when they go in, embarrassed, but I don't. They don't mess with me and I don't mess with them. They don't seem to treat me any differently than anyone else sitting there, like my wife and kids.

Hal has role identities as "father" and "husband" in addition to his criminal identity that he minimized to researchers through redemption scripts. His roles do not appear to converge in any meaningful way while registering or during home compliance visits. His interactions with sheriff deputies do not cause him any type of identity interruption. Although interactions force him to acknowledge his "criminal" identity, this does not seem to supplant, reinforce, or alter his other prosocial role identities.

Overall, our findings suggest that identities are not static, but they change, evolve, and transform as interactions change over time pre-conviction to post (Giordano et al., 2002). They also indicate that the internalization of stigmatizing labels does not necessarily occur upon attending degradation ceremonies or being officially labeled as "sex offenders." We did find a minority of cases in which interactions with deputies reminded people of their "sex offender" label, yet these men have not reoffended sexually or otherwise over the course of this study suggesting that these reminders may have little effect on their behaviors. We also found a few cases in which interactions with sheriff deputies help to reinforce or verify prosocial role identities. Last, to our surprise, in the majority of cases, interactions with deputies had little to no effect on role identities. We are left to speculate why interactions with sheriff deputies had disparate affects across registrants.

To contextualize these findings, we observed some variability in interactions across counties. In smaller counties with fewer sheriff deputies, participants noted more consistency in those who 
registered them and conducted home compliance checks. This reduced social distance between deputies and our participants, likely allowing more familiarity between parties and less focus on a stigmatizing label. In counties with larger populations and more sheriff deputies, participants perceived a "professional-personal dialectic" and some tension in their interactions with deputies resulting from the need for officers to deny friendships with sex offenders in front of others.

Another factor that likely affects how registrant/deputy interactions influence identity is how registrants interpret their criminal events. For those who believed they had sexual deviancy issues before arrest, registrant/deputy interactions were valued as they reminded people to manage their sexual deviant interests, much like Alcoholic Anonymous meetings remind people to manage their addiction. For those who internalized a "criminal" vs. a "sex offender" identity, interactions were largely seen as perfunctory exercises that created and reinforced an "ex-criminal" identity over time or had little to no effect on how registrants saw themselves. In contrast, for those who never accepted that their criminal convictions were deserved and believed their actions should not be crimes, interactions with deputies angered and frustrated them, they evoked continued redemption scripts across interactions over time, and interactions seemed to have negative effects on affective states and social distance between officers and registrants. Since all in our sample had not reoffended sexually or otherwise, we cannot say if increases in social distance had any effect on behaviors. We can say that interactions, under certain circumstances, did disrupt the verification of prosocial identities, but only for a relatively short period of time. Most interactions were largely inconsequential to identity.

\section{Discussion}

Based on prior literature (Mingus \& Burchfield 2012; Robbers, 2009; Tewksbury, 2012), we anticipated that the longer sex offenders were forced to interact with sheriff deputies under the "sex offender" label, the more verification they were likely to receive for a "sex offender" identity. This could harm efforts at desistance from sex offending. Instead, we found this to be the case only in certain situations. More often than not, interactions between our participants and deputies could create a new "ex-criminal" identity that was deemphasized and replaced by other conventional role identities as social distance decreased, or familiarity grew over time. Despite apprehension, conviction, and punishment, few identified as a "sex offender" before or after conviction, and the interactions they had with deputies did not diminish the interactions that verified identities as husbands, fathers, friends, and employees. Consistent with Matsueda (1992), this study concentrated on the mechanisms by which people come to internalize and adopt stigmatized identities over time. As Goffman (1963) suggested, several techniques were employed to help registrants avoid the internalization of their discrediting information, such as redemption scripts and generative stories (Maruna, 2001). The need for these techniques, however, changed dramatically the longer registrants interacted with deputies and social distance was decreased. 
Unexpectedly, participants made a distinction between a "criminal" and a "sex offender" identity. For these individuals, the "criminal" label was perceived as stigmatizing, but far less so than the "sex offender" label. When the sexual component of criminal behavior had to be recognized in interactions with officials, it was done so in the form of "group" identity (ten Bensel \& Sample, 2017) rather than self-identity. These subjects' perceived stigma was almost solely based on their group affiliation as "registrants," rather than individual behaviors, attributes, or character flaws (ten Bensel \& Sample 2017). In 2017, ten Bensel and Sample found that a collective identity forms around the recognition of the "sex offender" stigma, but it was "in-group" members and interactions that helped verify and reinforce conventional role identities of the group. A "communities of practice" (Eckert \& McConnellGinet, 1992; Lave \& Wenger, 1991) can form, in which people who share common stigmas and commitments to changing those stigmas offer interactions to create generative stories for group members to mitigate the internalization of a stigmatized identity (ten Bensel \& Sample 2017; Piazza \& Fasulo, 2014). As Piazza and Fasulo, (2014) suggested, in today's world, a two-way process occurs where individuals and groups can publicize their own versions of who they are, while also receiving a plurality of descriptions produced by external authoritative sources. We expected sheriff deputies to be agents of diffusion of "sex offender" stigma, but their interactions with registrants over time, either verified registrants' conventional identities or had no effect on identities at all (Kulick, 2005).

Most importantly, our study demonstrated how interactions with sheriff deputies help registrants verify new self-identities in ways that were consistent with how they have chosen to transform their "criminal" identities. For those who never internalized a "sex offender" identity, as seen in the majority of our sample, or have learned to avoid it, interactions with deputies served to verify a new identity as an "ex-criminal," or a person deserving of redemption and a second chance. Also, conventional role identities were verified that superseded the "criminal" label. For those who did see themselves as "sex offenders," interactions with deputies were welcomed verifications of this identity that helped promote continued vigilance toward change. Despite the frequency of interactions with deputies, registrants found that these interactions had little to no effect on self-identity, unless their affective states were already challenging their abilities to manage a group stigmatization in which they believed they were wrongly placed.

For years, scholars have assumed that successful reintegration into society for those labels as "sex offenders" has been hampered by this label and influenced people's abilities to see themselves as productive citizens (Evans \& Cubellis, 2015). We rarely considered that the external legal assignment of the "sex offender" label could be internally avoided. There are distinctions between "criminal" and "sex offender" identities that allow for redemption scripts and other stigma coping strategies. In addition, interactions with officials based solely on a "sex offender" status contributed to situational identities that were, at best, short-lived and did not permanently alter conventional role identities (Scott, 2015). 
Registration and notification laws were meant to morally condemn those who offend in sexual ways and enhance our ability to monitor these people's activities in the community. Regarding moral condemnation of these offenders, registrants have found people and created interactions that mitigate this condemnation over time. As social distance decreases, deputies can help transform criminal identities to ex-criminal identities that eventually are overcome by prosocial interactions. Also, after conducting this research, we find that the desire to monitor registrants' activities in the community appears to diminish as social distance between deputies and registrants decreases. In other words, deputies likely hold many of the same assumptions of labeled "sex offenders" as the public does when they begin their interactions, but these assumptions of dangerousness fade over time. In evaluations of the effects of registration and notifications laws, one must consider how their implementation varies over time.

\section{Implications and future research}

These findings suggested some practical implications for policy reform to help verify prosocial role identities and diminish "offender" identities. As the literature suggested, the narrowing of social distance and increased familiarity between registrants and deputies can help sex offenders recognize, verify, and reaffirm non-offending role identities (Bailey \& Sample, 2017). If police departments were to consistently assign the same people to work the registration desk and conduct home compliance visits, it is possible that registration could have positive effects on the identities of people convicted of sex crimes and their behaviors. Interactions over time could help prioritize conventional role identities over "offender" ones or at worst, they could have little to no influence in the identity transformation process.

Also, future research should continue to concentrate on the perceptions people convicted of sex crimes have of themselves. We were not prepared to find such a lack of internalization of the "sex offender" label. Prior quantitative and qualitive studies did not prepare us to see how inventive and creative people can be when coping with stigmatizing labels. Individual attributes such as affective states and personality types undoubtedly played a role in how people managed their "sex offender" label, with some moving past the label much more easily than others, but few of our study participants permanently struggled with interactions that emphasized their label. Even law enforcement agents could, over time, move beyond past behaviors and interacted with registrants as "ex-offenders" or as people working very hard to change themselves and their behaviors. We believe this finding demonstrates the need for data collection over time.

Again, how people see themselves is not static and it should not be studied as such. To understand the effects of a "sex offender" label on conventional activities such as employment, marriage, and child rearing, we must understand how people see themselves before, during, and after their criminal events. For too long, scholars have inferred that negative life outcomes for registrants are solely 
associated with their "sex offender" label. This study demonstrates that few internalized this label leaving use to speculate that they likely do not interact with people at work or at home based on this label. Recently, one research subject (Bob) lost his job and instantly believed it had to do with his "sex offender" status. After talking to Bob for one hour, it became clear to researchers that he was a victim of corporate downsizing and outsourcing, as were 20 other people at his company. He has since found another job equal to his last one and never once mentioned that his "sex offender" status prohibited his employment. His internalization of a "sex offender" label only seems to occur when life is presenting him with challenges. Data over time demonstrates that the internalization of "sex offender stigma" is episodic and situational. The stigma can be relied upon to understand negative life events but conversation and conventional role identities can cease internalization and force registrants to selfreflect, to judge their skill bases, and understand how larger economic trends, registrants' personalities and their affective states may have more to do with negative life outcomes than a "sex offender" label.

Last, given variability across policing agency within and across states, more studies are needed into registrants' interactions with law enforcement over time. There is limited research that has focused on registered citizens' perceptions of their interactions with the police and how it impacts their stigma management and self-identity. Scholars know very little about these interactions and the effects they have on internalizing, coping, or managing the "sex offender" label and/or role identity. This study provided initial insight into this gap in the literature by examining how registration-based interactions may influence the internalization of stigma and "new" identity construction, but was unable to isolate the effects of other salient interactions such as probation, parole, inmates, and non-criminal justice agents. Nonetheless, findings suggested that interactions with police, in some circumstances, influenced how registrants perceived and managed stigma and self-identity. While these findings are important, future research should focus on the nuances of certain circumstances and situations to help promote positive interactions and desistance from sex crimes. These interactions are imperative to our understanding of behavior because they may foster or inhibit behavioral outcomes such as desistance from sexual offending.

\section{References}

Anderson, E. (2000). Code of the Street: Decency, Violence, and the Moral Life of the Inner City. New York: W. W. Norton \& Company.

Ashforth, B. E., \& Kreiner, G. E. (1999). “How can you do it?": Dirty work and the challenge of constructing a positive identity. Academy of Management Review, 24(3), 413-434.

Bailey, D. J., \& Sample, L. L. (2017). Sex offender supervision in context: The need for qualitative examinations of social distance in sex offender-supervision officer relationships. Criminal Justice 
Policy Review, 28(2), 176-204.

Burke, P.J., \& Reitzes, D.C. (1981). The link between identity and role performances. Social Psychology Quarterly, 44(2), 83-92.

Burke, P. J., \& Stets, J. E. (2009). Identity theory. New York, NY: Oxford University Press.

Cooley, C. H. (1902). The looking-glass self. In Human Nature and the Social Order (pp. 179-185). New York: Scribner's.

Cooley, B. N., Moore, S. E., \& Sample, L. L. (2017). The role of formal social control mechanisms in deterring sex offending as part of the desistance process. Criminal Justice Studies, 30(2), 136-157.

Corbin, J., \& Strauss, A. (2015). Basics of qualitative research: Techniques and procedures for developing grounded theory (4th ed.). Thousand Oaks, CA: Sage.

Eckert, P., \& McConnell-Ginet, S. (1992). Communities of practice: Where language, gender and power all live. In Locating power: Proceedings of the second Berkeley women and language conference (Vol. 1, pp. 89-99). Berkeley, CA: Berkeley University.

Erikson, E. H. (1959/1994). Identity and the life cycle. New York: W. W. Norton \& Company.

Evans, D. N., \& Cubellis, M. A. (2015). Coping with stigma: How registered sex offenders manage their public identities. American Journal of Criminal Justice, 40(3), 593-619.

Evans, M. K., Lytle, R., \& Sample, L. L. (2014). Sex offender registration and community notification. In R. G. Wright (Ed.) Sex offender laws: Rhetoric and reality (2nd ed., pp. 142-164). New York, NY: Springer.

Frenzel, E. D., Bowen, K. N., Spraitz, J. D., Bowers, J. H., \& Phaneuf, S. (2014). Understanding collateral consequences of registry laws: An examination of the perceptions of sex offender registrants. Justice Policy Journal, 11(2), 1-22.

Giordano, P. C., Cernkovich, S. A., \& Rudolph, J. L. (2002). Gender, Crime, and Desistance: Toward a Theory of Cognitive Transformation. American Journal of Sociology, 107(4), 990-1064.

Goffman, E. (1963). Stigma. Notes on a spoiled identity. Englewood Cliffs, NJ: Prentice-Hall.

Harris, A. J., Levenson, J. S., Lobanov-Rostovsky, C., \& Walfield, S. M. (2018). Law enforcement perspectives on sex offender registration and notification: Effectiveness, challenges, and policy priorities. Criminal Justice Policy Review, 29(4), 391-420.

Hochstetler, A., Copes, H., \& Williams, J. P. (2010). “That's not who I am:” How offenders commit violent acts and reject authentically violent selves. Justice Quarterly, 27(4), 492-516. 
Jacobs, B. A., \& Wright, R. (2008). Moralistic street robbery. Crime \& Delinquency, 54(4), 511-531.

James, W. (1890). The consciousness of self. The principles of psychology (Vol. 1). New York, NY: Henry Holt \& Co.

Klein, J. L., Bailey, D. J., \& Sample, L. L. (2018). Researching the registered: challenges and suggestions for researchers studying sex offender populations. Criminal Justice Studies, 31(2), 192-211.

Kulick, D. (2005). Four hundred thousand Swedish perverts. GLQ: A Journal of Lesbian and Gay Studies, 11(2), 205-235.

Kvale, S. \& Brinkmann, S. (2009). Interviews: Learning the craft of qualitative research interviewing. Thousand Oaks, CA: Sage publication.

Lageson, S. E., \& Maruna, S. (2018). Digital degradation: Stigma management in the internet age. Punishment $\&$ Society, 20(1), 113-133.

Lave, J., \& Wenger, E. (1991). Situated learning: Legitimate peripheral participation. Cambridge university press.

Lea, S., Auburn, T., \& Kibblewhite, K. (1999). Working with sex offenders: The perceptions and experiences of professionals and paraprofessionals. International Journal of Offender Therapy and Comparative Criminology, 43(1), 103-119.

LeBel, T. P. (2012). Invisible stripes? Formerly incarcerated persons' perceptions of stigma. Deviant Behavior, 33(2), 89-107.

Levenson, J. S., \& Cotter, L. P. (2005). The effect of Megan's Law on sex offender reintegration. Journal of Contemporary Criminal Justice, 21(1), 49-66.

Lieblich, A., Tuval-Mashiach, R., \& Zilber, T. (1998). Narrative research: Reading, analysis, and interpretation (Vol. 47). Thousand Oaks, CA: Sage.

Lofland, J. (1969). Deviance and Identity. Englewood Cliffs, NJ.: Prentice Hall.

Maruna, S. (2001). Making good: How ex-convicts reform and rebuild their lives. Washington, DC: American Psychological Association.

Matsueda, R. L. (1992). Reflected appraisals, parental labeling, and delinquency: Specifying a symbolic interactionist theory. American Journal of Sociology, 97(6), 1577-1611.

Mead, G. H. (1934). Mind, self and society (Vol. 111). Chicago, IL: University of Chicago Press. 
Meisenbach, R. J. (2010). Stigma management communication: A theory and agenda for applied research on how individuals manage moments of stigmatized identity. Journal of Applied Communication Research, 38(3), 268-292.

Mingus, W., \& Burchfield, K. B. (2012). From prison to integration: Applying modified labeling theory to sex offenders. Criminal Justice Studies, 25(1), 97-109.

Opsal, T. D. (2011). Women disrupting a marginalized identity: Subverting the parolee identity through narrative. Journal of Contemporary Ethnography, 40(2), 135-167.

Paternoster, R., \& Bushway, S. D. (2009). Desistance and the 'feared self:' Toward an identity theory of criminal desistance. Journal of Criminal Law and Criminology, 99(4), 1103-1156.

Piazza, R., \& Fasulo, A. (Eds.). (2014). Marked Identities: Narrating lives between social labels and individual biographies. Basingstoke, Hampshire: Palgrave Macmillan.

Pierce, J. L., Maynes, M. J., \& Laslett, B. (2008). Telling stories: The use of personal narratives in the social sciences and in history. Ithaca, NY: Cornell University Press.

Powell, M., Day, A., Benson, M., Vess, J., \& Graffam, J. (2014). Police officers' perceptions of interviewing offenders on sex offender registries. International Journal of Police Science $\mathcal{E}$ Management, 16(4), 255-266.

Powers, W. T. (1973). Behavior: The control of perception. Chicago: Aldine Publishing Company.

Robbers, M.L. (2009). Lifers on the outside: Sex offenders and disintegrative shaming. International Journal of Offender Therapy and Comparative Criminology 53(1), 5-28.

Rocque, M., Posick, C., \& Paternoster, R. (2016). Identities through time: An exploration of identity change as a cause of desistance. Justice Quarterly, 33(1), 45-72.

Sample, L. L., \& Bray, T. M. (2003). Are sex offenders dangerous? Criminology \& Public Policy, 3(1), 5982.

Sample, L. L., Cooley, B. N., \& ten Bensel, T. (2018). Beyond circles of support: "Fearless"-An open peer-to-peer mutual support group for sex offense registrants and their family members. International Journal of Offender Therapy and Comparative Criminology, 62 (13), 4257-4277.

Sampson, R. J., \& Laub, J. H. (2003). Life-course desisters? Trajectories of crime among delinquent boys followed to age 70. Criminology, 41(3), 555-592. 
Sandler, J. C., Freeman, N. J., \& Socia, K. M. (2008). Does a watched pot boil? A time-series analysis of New York State's sex offender registration and notification law. Psychology, Public Policy, and Law, 14(4), 284-302.

Scott, S. (2015). Negotiating identity: Symbolic interactionist approaches to social identity. Cambridge, UK: Polity Press.

Stone, G. (1962). Appearance and the self. In A. Rose (Ed.), Human behavior and social processes (pp. 86118). Boston: Houghton Mifflin.

Stryker, S. (1980). Symbolic interactionism: A social structural version. Menlo Park, CA: BenjaminCummings Publishing Company.

ten Bensel, T., \& Sample, L. L. (2019). Social inclusion despite exclusionary sex offense laws: How registered citizens cope with loneliness. Criminal Justice Policy Review, 30(2), 274-292.

ten Bensel, T., \& Sample, L. L. (2017). The influence of sex offender registration and notification laws on fostering collective identity among offenders. Journal of Crime and Justice, 40(4), 497-511.

Tewksbury, R. (2005). Collateral consequences of sex offender registration. Journal of Contemporary Criminal Justice, 21(1), 67-81.

Tewksbury, R. (2012). Stigmatization of sex offenders. Deviant Behavior, 33(8), 606-623.

U.S. Department of Justice. Office of Sex Offender Sentencing, Monitoring, Apprehending, Registering, and Tracking. (2020). Current Law. Retrieved from https://smart.ojp.gov/sorna/currentlaw.

Vess, J., Day, A., Powell, M., \& Graffam, J. (2013). International sex offender registration laws: Research and evaluation issues based on a review of current scientific literature. Police Practice and Research, 14(3), 205-218.

Walfield, S. M., Levenson, J. S., Cubellis, M. A., Harris, A. J., \& Lobanov-Rostovsky, C. (2017). Law enforcement views on sex offender compliance with registration mandates. American Journal of Criminal Justice, 42(4), 807-832.

Wright, R. T., \& Decker, S. H. (2011). Armed robbers in action: Stickups and street culture. Lebanon, NH: University Press of New England.

Wright, R.T., Decker, S. H., Redfern, A. K., \& Smith, D. L. (1992). A snowball's chance in hell: Doing fieldwork with active residential burglars. Journal of Research in Crime and Delinquency, 29(2), 148-161. 
Zanna, M. P., \& Cooper, J. (1976). Dissonance and the attribution process. In J.H. Harvey, W.J. Ickes, and R.F. Kidd (Eds.), New directions in attribution research (Vol. 1, 199-217). Hillsdale, NJ: Erlbaum.

Zevitz, R., \& Farkas, M. (2004). Sex offender community notification: Managing high risk criminals or exacting further vengeance? In M. Pogredbin (Ed.), About criminals: A view of the offender's world (pp. 375-391). Thousand Oaks, CA: Sage.

\section{Contributors}

Lisa L. Sample, Ph.D. is a Reynolds professor in the School of Criminology and Criminal Justice at the University of Nebraska at Omaha. Her research interests include criminal and juvenile justice policy. More specifically, she conducts research in juvenile and criminal justice sentencing disparities, drug control policies, prison reentry programs, and sex offender behavior and policies. She has published in Criminology and Public Policy, Criminal Justice Policy Review, Crime \& Delinquency, Justice Quarterly, among other journals. Her email address is lsample@unomaha.edu.

Brooke N. Cooley, Ph.D. is an assistant professor in the Department of Criminal Justice and Criminology at Ball State University. Her research interests include corrections, institutional management, special populations within correctional facilities, and sex offender behavior and policies. She has published in Criminal Justice Studies, Journal of Crime and Justice, Corrections: Policy, Practice and Research, and International Journal of Offender Therapy and Comparative Criminology. Her email is bncooley@bsu.edu.

Tusty ten Bensel, Ph.D. is an Associate Professor in the Department of Criminal Justice at the University of Arkansas at Little Rock. She specializes in research on sexual violence and victimization, women and crime, identity changes, and reentry. Her email is ixzohra@ualr.edu.

Carin Hyter is the Drug Court Coordinator for Winona County, MN. She received her Bachelor's degree in Law and Society with a minor in Political Science from Winona State University in 2013. She graduated with her Master's degree in Criminal Justice with an emphasis in Public Administration in 2015 from the University of Nebraska at Omaha. She previously worked at the Douglas County Department of Corrections in Omaha, NE as the Pretrial Service Coordinator. Her email address is chyter@co.winoma.mn.us.

Brett Hurley is the Assistant Police Chief of the Houston Police Department in Houston, MN. He received his Bachelor's degree in Criminal Justice from Winona State University in 2011 and his Master's degree in Criminal Justice with an emphasis in Public Administration in 2015 from the University of Nebraska at Omaha.

\section{Reviews}

